\title{
El archivo como dispositivo de comunicación y memoria en el documental El padre mío de Diamela Eltit, Lotty Rosenfeld y Juan Forch
}

\section{The archive as communication and memory device in the documentary "El Padre Mío" from Diamela Eltit, Lotty Rosenfeld and Juan Forch}

Resumen El artículo presenta un análisis del documental El padre mío (1985) realizado por las/los artistas chilenos, Diamela Eltit, Lotty Rosenfeld y Juan Forch. La investigación se centra en el uso del material de archivo recuperado por Ixs autorxs que sirve de base al video. El documental revisa la figura del padre todo poderoso a través la imagen de Augusto Pinochet y su contrapartida, un vagabundo. Sobre el audiovisual del dictador se imprimen las voces y las imágenes de los olvidados por las políticas sociales y económicas del gobierno de facto. En este caso, el archivo funciona como un dispositivo de comunicación que permite visitar y pensar el lugar de memoria en contextos represivos.

\begin{abstract}
The paper presents an analysis of the documentary El padre mío (1985) performed by Chilean artists, Eltit, Lotty Rosenfeld and Juan Forch. The research focuses on the use of archival material recovered by the authors and which forms the basis of the video. The documentary reviews the almighty father figure through Augusto Pinochet's image and its counterpart, a tramp. The voices and images of the forgotten ones by social and economic policies are printed on the body of the archive. In this case, the archive works as a communication device that allows us to visit and think the place of memory in repressive contexts.
\end{abstract}

Palabras clave Memoria, archivo, documental, padre, dictador

Key Memory, archive, documentary, father, dictator words 


\section{Introducción}

En el presente artículo realizamos un análisis del documental El padre mío (1985) de Diamela Eltit, Lotty Rosenfeld y Juan Forch. Especialmente, nos centramos en el uso del material de archivo recuperado por los autores en el audiovisual mencionado. Los documentos aglutinados en este caso son la imagen del dictador chileno en un acto conmemorativo y la voz de Padre mío, un vagabundo de la comuna de Conchalí. El primero de ellos resulta el registro de un discurso de Augusto Pinochet transmitido por cadena nacional y, por lo tanto, de circulación masiva. La grabación fue tomada de la televisión comercial chilena, -en ella Pinochet conmemora un año más del golpe de Estado- sin dar detalles sobre el año de emisión. El acontecimiento periodístico en este caso procura perpetuar el carácter solemne del personaje masculino y los valores patrióticos que encarna. Nos interesa leer el archivo de este registro como un cuerpo que es intervenido de manera tal que pierde la fuerza ilocutiva primaria como desarrollamos a lo largo de este artículo.

El uso del material por parte de los creadores desarticula absolutamente el tono original al silenciar el archivo y ponerlo en diálogo con voces periféricas. En esa tensión, el documental discute la figura de autoridad y los discursos que la sostienen. Por ese motivo, de las nueve acepciones de la palabra "archivo" que discrimina la Real Academia Española resaltamos tres: conjunto ordenado de documentos, el lugar donde se custodian los mismos y conjunto de la información, esta última asociada al campo de la informática El modo, el espacio y la información forman parte de las aristas de la definición de archivo.

Los documentos tienen una vehiculación determinada y el acceso es restringido a un grupo específico de personas. Así se condiciona la libertad de los saberes que portan los archivos. Los artistas realizan un documental que desplaza el cerco político del registro y discute el lugar del poder. Por este motivo, nos permitimos hablar de interferencia del

1 El video puede observarse online en la web del proyecto de investigación U-matic que cuenta con el apoyo del Consejo Nacional de la Cultura y las Arte, Unesco-Chile y la Universidad ARCIS entre otras instituciones. Un equipo de responsables reúne en su archivo los videos realizados en formato 3/4 de pulgada (U-matic) entre los años 1977 y 1990 en Chile. El padre mío participa en el Cuarto Encuentro Franco-Chileno de Video Arte, Santiago de Chile, noviembre 1984. En aquella participación, según el catálogo, la duración es de 12 minutos. En la website del proyecto, el video documental cuenta con 9 minutos y 40 segundos por lo que los investigadores suponen un ajuste posterior a la emisión realizada en el encuentro. El material conservado por U-matic es un DVD Antología Digital 1977 - 2003 realizado por la propia autora, Lotty Rosenfeld. Otro dato importante es la autoría del mismo. El video expuesto presenta a Diamela Eltit, Lotty Rosenfeld y Juan Forch como autores de El padre mío. Este último integrante aparece solo en la versión final del cortometraje. La política del proyecto es mencionar a los tres y conservar, de esta manera, la propuesta de los realizadores. Sin embargo, la ficha técnica de El padre mío sólo postula a las autoras. Ver: http://www.umatic.cl/ 
archivo al transformarlo en un material permeable y plástico. A través de la manipulación y su contrapunto con el resto de los documentos, se pone sobre el tapete la perversa política impuesta en pos de unos pocos y en detrimento de muchos.

\section{El cuerpo del padre}

Los autores contraponen la figura de Augusto Pinochet con la del Padre mío mediante el contraste de dos soportes audiovisuales completamente diferentes: el material de archivo recuperado y el relevamiento audiovisual del vagabundo.

La metáfora del padre todopoderoso está concentrada en el cuerpo del material de archivo que expone el evento conmemorativo de la caída del gobierno de Allende (11 de Septiembre) llevado a cabo por el dictador y, sobre éste, imprimen los autores otro padre, menos central, menos poderoso, más periférico y frágil. Atraviesan este contrapunto de figuras masculinas otros personajes de condición marginal como niños, mujeres y locos.

El cuerpo del archivo se presenta como un cuerpo corrupto, cruzado y permeable a otras voces. De esta manera, los creadores se permiten invertir los signos de autoridad; especialmente, nos referimos al todo monolítico e incorrupto con que se presenta el poder para denunciarlo con fisuras, degradación, violencia y maldad. El paralelo entre el cuerpo del archivo y el cuerpo del dictador nos permite evidenciar el carácter subversivo de la obra de Eltit, Rosenfeld y Forch. Al hablar del cuerpo del archivo, hacemos referencia a la calidad del material y su soporte pero, además, al contenido del mismo ya que es importante en nuestro análisis no leer por separado forma y contenido. El valor patrimonial del archivo está íntimamente ligado a la sociedad que lo genera, como bien desarrolla Jacques Derrida en Exergo, y el estrecho vínculo entre el archivo y la autoridad de los arcontes.

Los arcontes son ante todo sus guardianes. No sólo aseguran la seguridad física del depósito

y del soporte sino que también se les concede el derecho y la competencia hermenéuticos. Tienen el poder de interpretar los archivos. Confiados en depósito a tales arcontes, estos documentos dicen en efecto la ley: recuerdan la ley y llaman a cumplir la ley. (1997: p.10)

La reflexión del filósofo francés nos permite hablar del archivo como el espacio de autoridad delegado y, conforme con la línea de pensamiento, el lugar de la perpetuación y reproducción de las políticas de dominio. Leonor Arfuch continúa la línea derridiana para destacar el archivo como un lugar singular atravesado por la temporalidad y permeable a continuas actualizaciones (2007). En otra perspectiva, Michel Foucault (1969) no concibe 
el archivo como un conjunto de documentos producidos en el pasado con la finalidad de conservar la memoria. El filósofo refiere a un "sistema general de la formación y de la transformación de los enunciados" (1969:221). Por este motivo, para profundizar la imagen del padre y entender mejor la peripecia de los artistas sobre el cuerpo del archivo traemos a nuestra investigación aportes vinculados a la filosofía, el psicoanálisis y los estudios de género. Estas disciplinas devanan el lugar de la autoridad en la estructura familiar y su relación con el lenguaje.

Con la pareja primigenia, madre y padre, se establecen los primeros balbuceos de un lenguaje articulado y, de esta manera, surge el universo dicotómico dictado por la hegemónica Ley del padre en la que se inserta el sujeto a obliterar el discurso de la mujer. Julia Kristeva discute, precisamente, este aspecto al reflexionar en su obra, Al comienzo era el amor: psicoanálisis y fe (1986), el famoso versículo Jn, 1.1-3 del Evangelio según San Juan (1995: 1097): “Al principio ya existía la Palabra, y la Palabra era Dios”. La crítica delibera sobre el génesis expuesto en el libro de Juan con el origen de la palabra y/o verbo retomando la lectura que Freud hace del mismo texto al hablar del "Nuestro Dios Logo". La filósofa activa el pensamiento del psicólogo austriaco para evidenciar el estrecho vínculo entre el sujeto y el lenguaje. Conjunción clave en el entramado social que coloca al sujeto, según Kristeva, en un divorciado inaugural con lo que la autora reconoce como la memoria de la especie.

En tanto seres parlantes, desde siempre potencialmente parlantes, estamos, desde siempre, clivados, separados de la naturaleza. Y este desdoblamiento deja en nosotros la huella de procesos semióticos que son previos al lenguaje o que lo trascienden, y que son nuestra única vía de acceso a la memoria de la especie o a los mapas neuronales bioenergéticos. (1986: p. 23)

Es potente la alusión a la "memoria de la especie" que menciona la autora como resabio de un pasado pre-verbal ya que nos permite asociar directamente este punto con la obra abordada. Mientras el discurso oficial se establece como un recorrido lineal y homogéneo, el documental se hilvana sobre una serie de yuxtaposiciones y fracciones emergentes de las contradicciones de la figura de poder como veremos en el desarrollo del análisis.

Las reflexiones de Kristeva vinculan el sujeto, con el verbo y el mundo en una relación iniciática hacia la cultura tomando estos conceptos del trabajo previo de Jacques Lacan. 
Estos tres elementos se articulan a través de la palabra de manera que, siguiendo al psicoanalista, entramos en el mundo o al registro de lo simbólico, es decir, mediante la palabra. Ahora, es cuando introduce el concepto de Ley o Ley del padre que se entiende por la acción de "clivaje" o castración sobre el párvulo al ser separado de la madre a través de la función paterna (Lacan, 2010). Ese acto de separación inserta al niño en el orden simbólico, es decir, en la cultura. La crítica a Freud y Lacan no se deja esperar y desde las líneas feministas hablan de una preponderancia hacia el falogocentrismo como manifestación del patriarcado (Butler, 2001 \& Irigaray, 2009)². En este sentido, los artistas chilenos ubican su obra en esa inflexión y juegan a través de la fragmentación del lenguaje; de allí, la tendencia a romper con las líneas del sintagma.

¿Buscan una memoria escindida? ¿Dónde se produce la inflexión? Elisabeth Roudinesco destaca los roles sociales de cada uno de los integrantes de la familia y profundiza la proyección que estos han tenido en la configuración de los imaginarios de género.

La doble temática del padre separador, dotado de cultura y cogito, fuente de libertad y alimento espiritual, y de la madre, naturaleza exuberante hecha de fluidos y sustancias, fue uno de los grandes componentes de la representación judeocristiana de la familia. Será retomada como herencia, después de sufrir serias revisiones, por la filosofía de la llustración y el psicoanálisis. (2004: p. 26)

Los téminos desarrollados por Elisabeth Roudinesco asocian al padre con la palabra, y por consiguiente con la cultura, mientras la madre carga los signos vinculados a la naturaleza y lo instintivo. Dos polos que se hacen eco en diferentes disciplinas. En el artículo, analizamos la imagen y voz del progenitor como sujeto introductor que se construye en el archivo sobre el cual gira el documental y abordamos a través de ellos el rol de padre en el contexto latinoamericano. Este último adquiere una valoración simbólica distintiva según Sonia Montecino en su obra Madres y huachos. Alegorías del mestizaje chileno (1996). La tradición mestiza ha cobrado un número significativo de hijos fuera del hogar generando un vínculo madre-hijo con ausencia del padre.

2 Judith Butler revisa los presupuestos lacanianos como es su versión del orden simbólico de herencia freudiana y su reflexión sobre las Estructuras Elementales del Parentesco de Lévi-Strauss. Ver: Butler (2001). Por otro lado, Luce Irigaray desarrolla en su ensayo Ese sexo que no es uno: "Desde esta perspectiva, cabe suponer que el falo (el Falo) es la figura actual de un dios celoso de sus prerrogativas, que pretende, en calidad de tal, ser el sentido último de todo discurso, el patrón de la verdad y de la propiedad, especialmente del sexo, el significante y/o el significado último de todo deseo, que además, en tanto que emblema y agente del sistema patriarcal, continuará respaldando el crédito del nombre del padre (el Padre)" (2009: p. 50). 
Pensemos que el hueco simbólico del Pater, en el imaginario mestizo de América Latina, será sustituido con la figura masculina poderosa y violenta: el caudillo, el militar, el guerrillero. El padre ausente se troca así en presencia teñida de potestad política, económica y bélica. Presencia que llena el espacio que está fuera de la casa; pero que impone en ella el hálito fantasmático de su imperio, aunque sea sólo por evocación o visión fugaz. (1996: p. 33)

La figura de poder que significa el padre se traslada en las sociedades latinoamericanas a las figuras de autoridad como bien lo explica Montecino ${ }^{3}$. Así, la imagen de potestad se erige como un todo monolítico e infranqueable que tiene eco en el microcosmos familiar. Se densifica el carácter masculino del poder y el padre adquiere un rol central en la distribución social. Por este motivo, el cordón periférico se engruesa a partir de éste en la medida que el padre todopoderoso expulsa a sus hijos con la implementación de un modelo excluyente.

La metáfora filial es pertinente a lo largo de esta investigación. El título de documental sitúa al espectador desde un inicio en una situación familiar: El padre mío. La alusión expresa al progenitor nos abre varias lecturas que van destinadas a la figura del dictador como padre todopoderoso. Sin embargo, la apropiación que realizan los autores habla de un patriarca fracturado, estallado y disuelto en la manía de un cuerpo errante como es el del vagabundo sucio, desarraigado y sin lazos afectivos.

Nos parece importante aclarar que el título del documental hace referencia al personaje errático que se autodenomina el Padre mío como bien explica Eltit en el libro homónimo que edita unos años más tarde. El espectador del audiovisual desconoce este dato y su referencia son las imágenes masculinas y la repetición del nombre en el discurso del lumpen. El título, además, permite un entroncamiento con la oración bíblica El padre nuestro, el pronombre posesivo singular desestima el valor comunal del rezo católico aludiendo a un padre personal e individual.

La imagen de Pinochet se hace presente y se desvanece a su vez en diferentes actores con los que se contrapone. Sobre su figura se imprime la voz del vagabundo y su

3 La literatura latinoamericana ha dado ejemplos muy jugosos sobre el tratamiento de la figura paterna como, por ejemplo, Pedro Páramo (1955) de Juan Rulfo donde se articula la búsqueda de Juan Preciado de su padre abandónico con la polifonía del texto que construye este personaje. Al hallarlo encuentra al caudillo dictatorial, al padre eclesiástico codicioso, al padre conquistador enloquecido por el oro, al padre Dios distante y sordo. Por otro lado, el conocido subgénero literario, novela del dictador, aborda la complejidad de los sujetos dictatoriales que se erigen desde el poder y el orden patriarcal. Obras narrativas como El señor presidente (1946) de Miguel Ángel Asturias, El otoño del patriarca (1970) de Gabriel García Márquez, Yo, el supremo (1974) de Augusto Roa Bastos, La fiesta del Chivo (2000) de Mario Vargas Llosa, etc. son algunos ejemplos de este subgénero que complejiza la imagen masculina del poder autoritario o el caudillismo. 
elocuente testimonio vinculado a la conspiración política y económica. Por este motivo, vale cuestionar, siguiendo el razonamiento planteado, qué discurso imprime este padre omnipresente a través de las voces de los otros.

\section{En el nombre del padre. El uso de imágenes de archivo y el registro audiovisual}

El Padre mío fue presentado en el Cuarto Encuentro Franco-Chileno de Videoarte en la cuidad de Santiago en 1984. El catálogo del encuentro contiene la sinopsis del documental donde se focaliza la dependencia entre el padre y los excluidos del sistema a través de la imagen de Augusto Pinochet. La distribución de los actores sociales se manifiesta en el montaje del video y en el contrapunto entre la figura del dictador y los sujetos marginales.

La relación del padre todopoderoso representado en la figura de Pinochet, pero también en las voces de niñas, mujeres y dementes que aluden a su relación filial. // El video se estructura en torno al entrecruzamiento y fusión de 3 espacios antagónicos. -Reunión cultural de mujeres en una población de extrema pobreza. -Grabación tomada de la TV comercial chilena, en la cual Pinochet conmemora un año más del golpe de Estado. Imagen y discurso de un indigente esquizofrénico que habita en un eriazo periférico. (U-matic, edición online) ${ }^{4}$

En el trabajo conjunto, Eltit, Rosenfeld y Forch se nutren mutuamente para dar forma a la agónica demanda social de los excluidos chilenos. A través del material relevado en diferentes espacios, los artistas conjugan cuerpos y voces marginales a las que contraponen con la imagen de archivo del dictador. Ambas creadoras poseen un número significativo de trabajos en colaboración desde su participación en el grupo interdisciplinario CADA (1979-1983) hasta la actualidad. Video arte, performances, acciones de arte, libros e instalaciones son algunos de los formatos en los que han incursionado conjuntamente Diamela Eltit y Lotty Rosenfeld. ${ }^{5}$

En el documental experimental ${ }^{6}$, el cuerpo sobre el que se aborda el conflicto es el cuerpo mismo del archivo. Es decir, los autores fragmentan el documento audiovisual dedicado

\footnotetext{
4 De esta manera figura la sinopsis del documental en el catálogo del Cuarto Encuentro Franco-chileno de Video Arte de 1984 donde fue presentado, El padre mío. Ver: http://www.umatic.cl/detalle_completo.php?id=485

5 Patricia Rubio analiza el trabajo de dos décadas de colaboración de ambas artistas chilenas. Las obras como Traspaso cordillerano, ¿Quién viene con Nelson Torres?, Tajo abierto en la memoria e Historia del sufragio femenino forman parte del corpus de la crítica chilena. Ver: RUBIO, Patricia (2005), "Escritura/Imagen: acercamientos a la colaboración artística entre Diamela Eltit y Lotty Rosenfeld". En: André, María Claudia y Patricia Rubio (2005) Entre mujeres: colaboraciones, influencias e intertextualidad en la literatura y el arte latinoamericano. Santiago de Chile, RIL Editores.

6 En la categoría "documental experimental" figura en el catálogo del Cuarto Encuentro Franco-Chileno de Video Arte en 1985.
} 
al acto en honor al aniversario del golpe de Estado, cuyo protagonista principal es Augusto Pinochet Ugarte. Originalmente, este material fue grabado por la televisión abierta ("TV comercial chilena", según la sinopsis del catálogo), los realizadores toman el registro volviendo poroso el cuerpo del archivo seleccionado. En otras palabras, inscriben sobre el material otros cuerpos y otras voces y, lo vuelven permeable a los discursos silenciados por el mismo sistema que tiene como ejecutor capital a Pinochet y su contrafigura, el Padre mío.

La imagen del dictador se discute desde el propio diseño del documental. Principalmente, la presencia de un archivo interfecto ${ }^{7}$ que entra en diálogo con otros registros más anónimos y menos publicitados gracias a la intervención de las artistas. El giro político, económico y social que sacudió al país genera entre tantas transformaciones un cambio radical que Eltit reconoce como la desaparición del proyecto progresista de Allende.

La propuesta de Allende, basada fundamentalmente en una mayor justicia social, al triunfar en 1970 llevó a los sectores populares a un protagonismo inédito en nuestra historia. Sus hablas, sus fisonomías, sus estéticas, ocuparon el espacio público desde la legitimidad de un gobierno que respaldaba esa ocupación causando, obviamente, conmoción entre los asentados siquismos conservadores. (2008: p. 97-98)

El proyecto se ve truncado en manos del modelo de libre mercado y la política de exclusión social como consecuencia directa. Un giro de ciento ochenta grados da vuelta la escena durante dos décadas de gobierno militar. Los cuerpos regresan a la periferia y al ostracismo con los estigmas sociales inscriptos en la carne. La ciudad se tiñe de la hipocresía, la mediocridad de la burguesía santiaguina incapaz de defenderse del atropello y acepta la propia denigración.

En esta línea descripta, los realizadores articulan el relevamiento audiovisual del arrabal chileno en busca de esos cuerpos desplazados y los colocan sobre el material de archivo. Recuperan el proyecto social de Allende al exponer las hablas, las fisonomías y las estéticas de los sectores más sensibles de la sociedad chilena.

7 Al hablar de un archivo interfecto hacemos alusión a un material que ha sido abatido en su función primaria y ha perdido su característica originaria y que, en el caso trabajado, se pone a disposición de otros registros. Leonor Arfuch destaca la capacidad del archivo de actualizarse según el "régimen de la mirada", en este caso, la intervención de los autores consiste en subvertir los signos del original (2007). En consonancia, George Didi Huberman (2004) reconoce que la clasificación del archivo es ya una interpretación que permite hacer uso del mismo. La exhumación del archivo es una actividad recurrente en el arte contemporáneo y que destacamos en los trabajos de Eltit. Diferente es el abordaje de los testimonios que registra el documental como son los casos de la niña, las mujeres y los locos donde se recuperan las voces silenciadas por el sistema. 
El archivo audiovisual se presenta como una suerte de palimpsesto vanguardista cuestionador. De esta manera, la imagen del dictador y los discursos que sostienen una época controversial se filtran a través de las capas de montaje del audiovisual. En el nombre del padre se silencia, se excluye, se reprime, se condena y se desaparece.

\section{La sintaxis de los cuerpos bastardos}

La secuencia del acto conmemorativo está dividida en tres escenas o momentos: la llegada del dictador al recinto, éste y sus guardaespaldas se abren paso entre la multitud; el discurso de Augusto Pinochet, el plano fijo expone su figura detrás de los micrófonos; sobre su costado derecho se observa un efectivo de seguridad y, finalmente, de pie junto a un guardia a su izquierda en actitud solemne aparece el represor. Sobre esta potente imagen se funden el cuerpo y la voz del Padre mío, el lumpen ${ }^{8}$ del arrabal santiaguino.

La figura de Pinochet se expone siempre en plano medio haciendo ostensible el uniforme de gala correspondiente a los actos conmemorativos, las condecoraciones militares y la banda presidencial que atraviesa su pecho con los colores de la bandera chilena. El dictador se encuentra custodiado por los guardaespaldas que le otorgan relevancia a la figura. La escena expuesta obvia rotundamente el escenario o el motivo de la presencia del mandatario en el recinto: sólo presenta en cámara lenta el blindado de un cuerpo que se sabe soberbio, integro e incorrupto. Su vestuario y ornamentos, su desplazamiento y entorno hablan sobre la envergadura de la imagen del dictador. Sin embargo, es ese el cuerpo-bloque que los autores quiebran en función de otorgar presencia a otros cuerpos. Y es allí donde radica, a nuestro entender, el carácter subversivo de la obra trabajada.

Leer el archivo como un cuerpo insoldable o como piezas truncas en coalición con otros textos nos parece el arriesgado desafío que propone el documental. La sintaxis del video se articula sobre la fragmentación y el contraste de voces e imágenes. Manifestaciones sociales callejeras, niños en el salón de una escuela, mujeres demandando derechos negados,

\footnotetext{
8 El término lumpen proviene del idioma alemán, andrajoso/a o lumpemproletariado que según la Real Academia Española indica "la capa social más baja y sin conciencia de clase" (RAE, edición digital). El vocablo es introducido en 18451847 por Karl Marx y Friedrich Engels en "La ideología alemana" (Die deutsche Ideologie) y, posteriormente, desarrollado 1851-1852 en la obra, "El dieciocho brumario de Luis Bonaparte" (Der Achtzehnte Brumaire des Louis Bonaparte) de Karl Marx. En esta última obra, el filósofo alemán da las características de los personajes sociales que se reúnen bajo el término lumpemproletariado: "[...]vagabundos licenciados de tropa, licenciados de presidio, esclavos huidos de galeras, timadores, saltimbanquis, lazzarroni, carteristas y rateros, jugadores, maquereaux, dueños de burdeles, mozos de cuerda, escritorzuelos, organilleros, traperos, afiladores, caldereros, mendigos; en una palabra, toda esa masa informe, difusa y errante que los franceses Ilaman la bohème[...]" (Marx, C. y Engels, F. 1968: p. 86).
} 
conjunto de internos de un centro psiquiátrico son algunos de los personajes que circulan en el audiovisual. Sobre estos cuadros se solapan y funden las figuras de Augusto Pinochet y del Padre mío. Una suerte similar corre la banda sonora que intercepta las voces de las multitudes, de la niña, mujeres y risas de los internos con la voz del vagabundo silenciando $y$, por otro lado, el discurso del dictador. Detalle no menor es la omisión por completo del audio del archivo que sucumbe ante las palabras marginadas por el régimen. El video se cierra con la imagen del lumpen que se funde a negro y su voz se transforma en un eco sobre la cortina oscura de los créditos finales como una suerte de sombría metáfora de la situación reinante en el país.

El intento de desglosar el video nos genera cierto recelo por el complejo entramado del mismo. Sin embargo, tal empresa merece la pena ya que al deshacer la trama pretendemos evidenciar características relevantes para el análisis del uso del material de archivo.

El video comienza con un proclama coral de "justica y libertad", inmediatamente surge una voz femenina en off a través de un megáfono mientras el sonido ambiente es el murmullo de la multitud. La primera imagen en plano general es un espacio abierto, una calle y casas aledañas, donde se encuentra una manifestación de personas. El plano se corta y, seguidamente, la cámara en contrapicado toma los pies de la multitud que ocupa la calle.

El plano recorre la manifestación enfocando hacia el suelo; a través de los zapatos y piernas de las personas congregadas en la manifestación lo que acerca a la tierra su visión y la contrapone con la escena siguiente. Los autores plantean una escena de descontento social. Una voz femenina hace eco en la multitud y se dirige hacia la masa: “1983 quedará marcado en nuestra historia... el pueblo unido jamás será vencido, y que nunca será vencido. Escuche, democracia verdadera", "Viva, Chile" y "El pueblo unido jamás será vencido". Aplausos al final de la escena y la imagen, seguidamente, se funde con figura de Pinochet ingresando a un recinto en plano medio largo acompañado de un guardaespaldas. El discurso de la mujer hace eco en la multitud y, gracias al montaje, el dictador es el destinatario del enunciado "Escuche". Durante un breve período las imágenes de la manifestación y de la figura masculina están solapadas.

Un punto a subrayar es la fecha que se resalta al comienzo del audiovisual: ésta no es casual y posee relevancia ya que a partir del año 1982 el modelo impuesto por el dictador 
comienza a mostrar las fisuras económicas y sociales. Los altos índices de recesión y el crecimiento negativo del país son uno de los problemas que debe enfrentar el gobierno y que continúan hasta el fin de la dictadura. Este hecho que genera brotes de reclamos en todo el país $y$, seguramente, el relevamiento realizado por los autores responde a una de esas manifestaciones.

Es importante destacar la articulación entre la imagen y el audio del documental. En esta escena la voz invade la multitud sin reconocer visualmente al locutor de la misma, una suerte de eco que homologa a todas las personas que se hallan reunidas en la manifestación. Los aplausos y arengas son la aceptación de un discurso común y plural en la voz femenina. El plano del gentío se funde hasta llegar a la escena de la escuela donde el espectador encuentra en plano medio a Marisol Díaz, una niña de 8 años leyendo un escrito que titula: “Qué ha pasado de mi vida?”. La cámara toma en un contexto escolar la niña en plano medio, el encuadre está centrada en su persona y en el fondo del cuadro se aprecian seis niños sentados en una banca. Allí, relata la tristeza que siente cuando su madre la deja al cuidado de otras personas, el dolor de ver a su padre golpeador y a su hermano que repite la historia paterna.

A medida de que su relato avanza, el plano se cierra sobre el rostro de la infante haciendo más cercano su narración al visualizador. Progresivamente su cara se desdibuja con la aparición del rostro y voz del Padre mío. En ese momento vuelve la imagen de Pinochet en plano medio dando un discurso mientras se mantiene la voz en off del esquizofrénico vagabundo. Estas tres escenas descriptas mantienen un elemento en común relacionado con la emisión de un determinado discurso. Los dos primeros suponen un auditorio menor y cerrado en la medida que el público, en el caso de la niña, es la comunidad escolar y en el Padre mío, la cámara. Sin embargo, el discurso de carácter celebratorio de Augusto Pinochet presupone un auditorio masivo, público y de repercusión nacional a diferencia de los dos anteriores. El locutor, en este caso el dictador, hace referencia seguramente a los progresos y los cambios realizados por política de derecha impuesta en Chile. Tema que presuponemos ya que, como mencionamos previamente, la banda sonora del archivo está completamente vedada.

9 La transcripción del relato de Marisol Díaz se diluye a medida que la próxima escena con Pinochet se solapa con la de ella: "Yo me llamo Marisol Díaz, tengo 8 años les contaré el cuento qué ha pasado de mi vida. Mi madre nos tiene que dejar encargados con otras personas y yo sufro porque mi papá le pega a mí mamá y no sé por qué mi hermano es igual que mi papá y yo sufro al ver a mi hermano repetir las mismas ... de mi papá. Y mi papá le puso a mi hermana un ... a mi hermano..." 
El silenciamiento del dictador por las voces de la menor y el resto de los sujetos que desfilan a través del documental es significativo y posee un valor vindicativo relativo a la represión y exclusión de esos años. De esta manera, el audio de los marginados adquiere peso testimonial sobre la figura de Pinochet, pone en foco la denuncia de los atropellos que padecen a causa del sistema, el mismo que celebra el represor en el archivo.

\begin{abstract}
Sabemos que el testimonio es llamado a desempeñar un rol estratégico en los contextos de violencia y destrucción sociales, de luchas históricas, porque su convención de objetividad acredita una verdad de los hechos que, con su referencialidad directa y probatoria, sirve de documento para fundar la veracidad del relato y volver entonces inobjetable el "haber sido" de la realidad a denunciar en nombre de sus víctimas. (Richard, 1998: p. 81)
\end{abstract}

El video documental exhibe voces y cuerpos como testimonios fidedignos de la crisis política, económica y social que contrasta con el uso del archivo en el que se desvirtúa el valor testimonial del documento de Augusto Pinochet. En este sentido, su función como custodio del pasado y registro del mismo se ve violentado y desarticulado en la práctica artística de los autores. Una situación muy diferente procede con el testimonio del esquizofrénico que escapa a las convenciones propias del género al perder, siguiendo a Nelly Richard, la veracidad del relato $(1998)^{10}$.

La figura y la banda de sonido ambiente se disuelven progresivamente, los planos de mujeres y una voz femenina se acoplan. La cámara recorre en un primer momento los rostros de las féminas mientras gradualmente el cuadro del dictador se diluye. La imagen se funde con la de un grupo de mujeres sentadas en un semicírculo. Esta imagen semicircular presenta semejanza con la iconografía de la vulva ${ }^{11}$ y promete una distribución menos jerárquica y más participativa opuesta al posicionamiento del dictador en el plano anterior. La verticalidad de la figura masculina se opone al resto de los personajes evidenciando el poder del falo. Regresamos al ágora de las mujeres; una de ellas habla a la audiencia femenina y su mensaje es la demanda de los derechos negados: "falta de participación en los gobiernos de los 70 y 80", "la falta de educación y de alimento" y "el reclamo como madre y como hija". Las mujeres ocupan en el documental un lugar preponderante y

10 Cuatro años más tarde y ante la desaparición del marginal, Eltit decide publicar la transcripción del registro oral del vagabundo. Este singular libro es el resultado de una búsqueda en pos de una "estética generadora de significaciones culturales" (2003). Observamos la necesidad de rescatar el testimonio del errático en función de un habla que la autora metaforiza como el propio Chile: "En esa honda crisis del lenguaje, una infección en la memoria, una desarticulación de todas las ideologías. Es una pena, pensé. Es Chile, pensé "(2003:15).

11 Esta iconografía relacionada con lo semicircular asemeja a una vulva y se repite en otras imágenes grupales femeninas. 
destacan su accionar como sujetos activos en defensa de sus derechos desde el rol de madre e hija. ${ }^{12}$

La imagen de la mujer se funde, primero sobre el perfil del Padre mío y luego esta figura se disuelve sobre Pinochet de pie y acompañado de un guardaespaldas. El plano medio largo, paulatinamente, se desvanece ante la escena de un grupo de dementes que juegan en el patio de un nosocomio. El divertimento radica en dibujar la silueta de un compañero sobre el muro del centro asistencial. Una vez realizado el contorno, el sujeto se separa de la pared para ver el trazado de su cuerpo plasmado en negro. Las risas y los aplausos surgen al ver la silueta grabada en la pared. Hay un contraste entre la rigidez de los cuerpos, la figura de Pinochet se sostiene sobre la solemnidad hacia el acto patriótico mientras que el cuerpo del interno se sostiene sobre el juego colectivo. Además, el entusiasmo y la alegría que genera el testimonio de la silueta inscripta sobre el muro es significativa ya que da muestra del contorno de cuerpos materiales y tangibles opuesto a los cuerpos desplazados del sistema, relegados a la asistencia del sistema médico quien traza sobre estos un dictamen disfórico y terminal confinando los cuerpos al cajón burocrático de turno.

El plano siguiente se centra en un joven que muestra a la cámara una bolsa y, seguidamente, comienza a aspirar de ella por lo que puedo inferir que encuentra pegamento en su interior. Los autores rescatan la acción del muchacho de acercar su droga a la cámara sin afán de ser sentenciado por ello. Sobre esta maniobra casi desafiante se solapan imágenes de marchas callejeras como las que dieron inicio al documental. Hombres y mujeres se desplazan por la calle y la cámara mantiene un plano general donde se puede observar la multitud avanzando.

La voz del Padre mío toma presencia cada vez más hasta que la imagen del demente se funde en la del homeless. Cadenas de frases se hilan vertiginosamente y afirmaciones como "Yo fui planeado para lo que estoy", "garantía de la administración para deshacerse de mi persona", etc. se agolpan en la boca del Padre mío. Voz e imagen en sincronía se cierran lentamente en un close up del Padre Mío. La voz del lumpen permanece sobre

\footnotetext{
12 Profundizamos esta estrategia de autorización, es decir, la "maniobra" de las mujeres para lograr cambios en su situación familiar y política. En palabras de Marcela Pizarro al aplicar su concepto sobre el análisis del texto de Gabriela Mistral, Conversando sobre la tierra (1931): "La estrategia de autorización en este caso consiste en asumir un papel asignado sin pretensiones de trastrocamiento, en donde el sujeto de la enunciación no va a producir sino a re-producir (escarderé) (los "lugares comunes"-"olvidados") en situación de subalternidad ("no servimos sino"). Una vez tranquilizado el interlocutor, a quien desde la primera línea se ha indicado la pertinencia de un discurso femenino sobre el tema (relación mujer-tierra) comienza una reformulación de espacios" (Pizarro, 1999: p. 191).
} 
el fondo negro de la imagen hasta que aparecen los créditos finales. El eco de la palabra repercute sobre el negro cierre y el espectador queda ante el testimonio de vagabundo.

Las secuencias se abren y se cierran con la imagen de Augusto Pinochet. La voz en off en el comienzo de la manifestación anuncian el advenimiento de un nuevo Chile, las mujeres reunidas en ágora demandan acciones sociales y exigen mayor participación, la palabra de la niña que denuncia la situación familiar. Es decir, el único testimonio mudo es el de Augusto Pinochet. El archivo como documento testimonial es utilizado en este sentido para desacreditar al protagonista y, por otro lado, dar voz a los que durante el gobierno del dictador fueron silenciados resultan políticas estéticas.

\section{El archivo del cuerpo y el cuerpo del archivo}

La imagen soberbia de Augusto Pinochet contrasta con la del marginalPadre mío. Esa yuxtaposición juega un reverso en la trama del documental. Su figura se impone aparentemente pero es eclipsada por las imágenes de los personajes excluidos por el propio modelo implementado por represor. La escena del discurso conmemoratorio presenta el audio del Padre mío siendo omitida la del propio locutor. De esta manera, el silenciamiento está en el que ejerce el poder en Chile. La voz velada del documental es la del dictador sobre la cual se imprimen los reclamos de los expulsados del sistema. "Escuche" es la primera demanda que inaugura el documental y apela directamente al dictador. Las minorías tienen la palabra en el video de Eltit-Rosenfeld-Forch. Sobre el traje militar de gala y la seguridad garantizada del guardaespaldas chocan las imágenes y los testimonios de los chilenos marginados. Desde su lugar periférico, mujeres, niños y locos enfrentan a la figura del padre magnánimo.

El documental es un espacio abierto a voces ocultadas y excluidas del sistema capitalista. El discurso presidencial que en el contexto descripto debiera hacer un recorrido por los éxitos del sistema impuesto es elidido por testimonios que encarnan el alcance de esos "éxitos". El archivo del cuerpo, es decir, cuerpo desplazado y reprimido expone los estigmas sociales de una política económica diseñada para los más fuertes. Entiéndase por fuertes los grandes magnates, las multinacionales y las empresas que se erigen sobre el saqueo, la codicia y latrocinio de los pueblos a través de la complicidad de la figura del poder. En el caso analizado nos referimos a la imagen de Augusto Pinochet y su filiación expresa con la comunidad chilena adinerada. 
El cuerpo popular es replegado en la periferia, se excluye y se lo silencia. La acción de Eltit, Rosenfeld y Forch es recuperar esas voces/cuerpos darles el espacio para la demanda, mientras las hilvana con la imagen del padre reproductor de una cultura de la excepción, aséptica y represiva.

Referencias Bordwell, D. (1995). El significado del film. España: Paidós.

Butler, J. (2001). El grito de Antígonas. Barcelona: El Roure Editorial.

De Lauretis, T. (1992), Alicia ya no. Feminismo, Semiótica, Cine. Madrid: Ediciones Cátedra.

Derrida, J. (1997). Mal de archivo. Madrid: Editorial Trotta.

Didi-Huberman, G. (2004). Imágenes pese a todo. Memoria visual del Holocausto. Barcelona: Editorial Paidós.

Eltit, D. (2003). El Padre Mío. Santiago: Libros del ciudadano.

- (2008). Signos vitales. Escritos sobre literatura, arte y política. Santiago: Ediciones Universidad Diego Portales.

Eltit, D., Rosenfeld, L.y Forch, J. (Directores) (1985). El Padre Mío. Santiago: Lotty Rosenfeld. Recuperada de http://www.umatic.cl/video15.html

Foucault, M. (1969). La arqueología del saber. Buenos Aires: Siglo XXI.

Forcinito, A, (2004). Memoria y nomadías: géneros y cuerpos en los márgenes del postfeminismo. Santiago: Editorial Cuarto Propio.

Hernández Navarro, M, (2007). El archivo escotómico de la Modernidad. Pequeños pasos para una cartografía de la visión. Alcobendas: Colección de Arte Público \& Fotografía, Ayuntamiento de Alcobendas.

Irigaray, L. (2009). Ese sexo que no es uno. Madrid: Akal.

Kristeva, J. (1988). Los poderes de la perversión. Buenos Aires: Catálogos Editora.

Lacan, J. (2000). Escritos 2. Buenos Aires: Siglo XXI.

Marx, K. y Engels, F. (1968). La ideología alemana. Montevideo: Ediciones Pueblos Unidos.

Montecino, S. (1996). Madres y huachos. Alegorías del mestizaje chileno. Santiago: Editorial Sudamericana.

Pizarro, A. (1994). De ostras y caníbales. Reflexiones sobre la cultura latinoamericana. Chile: Ed. Universidad de Santiago.

Richard, N. (1998). Residuos y metáforas. Santiago de Chile: Editorial Cuarto Propio

Roudinesco, E. (2004). La familia en desorden. Barcelona: Anagrama. 